\title{
SALMON GONADOTROPIN RELEASING HORMONE ANALOGUE STIMULASI PEMATANGAN SPERMATOFOR UDANG WINDU (Penaeus monodon) APKIRAN TANPA ABLASI
}

\author{
Ike Trismawanti", Agus Nawang, dan Asda Laining \\ Balai Riset Perikanan Budidaya Air Payau dan Penyuluhan Perikanan \\ Jl. Makmur Dg. Sitakka No. 129, Maros, Sulawesi Selatan 90512 \\ (Naskah diterima: 7 Desember 2017; Revisi final: 6 April 2018; Disetujui publikasi: 14 M ei 2018)
}

\begin{abstract}
ABSTRAK
Penggunaan induk pada pembenihan udang windu pada dasarnya hanya untuk periode yang singkat dan selanjutnya induk udang windu diapkir baik betina maupun jantan. Tujuan penelitian ini untuk mengevaluasi efek injeksi hormon kombinasi salmon gonadotrophin releasing hormone analogue ( $\mathrm{sGnRH}-\mathrm{a})$ dan domperidone terhadap karakteristik spermatofor induk udang windu, Penaeus monodon yang telah diapkir dari unit pembenihan tanpa ablasi tangkai mata. Dua tahap penelitian dilakukan pada udang windu jantan yang diapkir dari unit pembenihan. Tahap pertama terdiri atas dua dosis 0,1 (OV-1) dan 0,2 (OV-2) mL/kg bobot udang dan ablasi mata (AB) sebagai kontrol. Pada tahap ke-2, dosis yang diaplikasikan adalah dosis terbaik dari tahap ke-1 (OV-3) dan ablasi sebagai kontrol (AB). Induk jantan apkir ditebar masing-masing dengan kepadatan 14 ekor untuk tahap ke-1 dan 12 ekor pada tahap kedua. Injeksi dilakukan tiga kali dengan interval satu minggu untuk kedua percobaan tersebut. Seminggu setelah suntikan terakhir, induk jantan diberi kejutan listrik untuk mengeluarkan spermatofornya. Pada percobaan pertama, jumlah induk jantan yang mengeluarkan spermatofor pada maturasi dan rematurasi pertama lebih banyak ditemukan pada perlakuan OV-2 daripada OV-1 dan AB. Induk jantan pada perlakuan OV-3 pada tahap ke-2 menghasilkan lebih banyak spermatofor $(58,3 \%$ dibandingkan dengan $A B(50 \%$. Hubungan antara bobot badan dan bobot spermatofor untuk total data pada tahap ke-1 sifatnya linier dengan nilai $r=0,74$ sedangkan hubungan antara bobot spermatofor dan jumlah spermatozoa sifatnya tidak linier dengan nilai $r=0.14$. Induk apkiran jantan udang windu masih dapat memproduksi spermatofor melalui stimulasi injeksi hormon sGnRH-a pada dosis $0,2 \mathrm{~mL} / \mathrm{kg}$ bobot udang relatif lebih banyak dibandingkan ablasi.
\end{abstract}

\section{KATA KUNCl: $\quad$ sGnRH-a; spermatofor; jantan apkiran; udang windu}

ABSTRACT: Use of Salmon gonadotropin releasing hormone anal ogueto stimulate spermatophores maturation of hatchery-discarded male tiger shrimp (Penaeus monodon). By: Ike Trismawanti, Agus Nawang, and Asda Laining

Broodstocks in black tiger hatcheries are commonly used for only a short period of time. Both female and male broodstocks are discarded due to reduced spawning frequencies. This recent study was an effort to explore whether discarded broodstocks could be rematurated without eyestalk ablation. For the research purpose, a two-stage experiment was conducted on discarded male tiger shrimps to evaluate the effect of $\mathrm{SGnRH}$-a injection on the shrimp reproductive performances. In the first stage, the experiment consisted of injection treatment of different doses of sGnRH-a at 0.1 $(\mathrm{OV}-1)$ and $0.2(\mathrm{OV}-2) \mathrm{mL} / \mathrm{kg}$ and eyestalk ablation (AB) as a control. For the second stage, the treatment consisted of injection of sGnRH-a optimum dose obtained from the first trial $(0.2 \mathrm{~mL} / \mathrm{kg}$ shrimp $(\mathrm{OV}-3)$ and ablation as the control (AB). The treated male stocks were then randomly placed in concrete tanks with a density of 14 males/tank for the first stage and 12 males for the second stage. The injections were carried-out three times with an interval of one week for both stages. A week after the last injection, males were electrically shocked to release their spermatophores. In the first stage, the number of males releasing spermatophores at maturation and first re-maturation was higher in OV-2 treatment than that of $\mathrm{OV}-1$ and $\mathrm{AB}$ treatments. In the second trial, the number of males in $\mathrm{OV}-3$ treatment released more spermatophore $(58.3 \%$ compared to $A B$ which was $50 \%$ The body and spermatophore weights correlation of the

\footnotetext{
\# Korespondensi: Balai Riset Perikanan Budidaya Air Payau dan Penyuluhan Perikanan. Jl. Makmur Dg. Sitakka No. 129, Maros, Sulawesi Selatan 90512, Indonesia.

Tel.: + 62411371544

E-mail: ic_ast@ yahoo.co.id
} 
discarded tiger shrimp in the first trial followed a positive linear with an $r$-value of 0.74 . However, the spermatophore weight and the sperm cell number was not positively correlated with an r-value of 0.14 . The discarded male tiger shrimps produced a relatively higher spermatophore when induced with $\mathrm{sGnRHa}$ at a dose of $0.2 \mathrm{~mL} / \mathrm{kg}$ than those of shrimp treated with ablation.

\section{KEYWORDS: $\quad$ sGnRH-a; spermatophore; discarded male; tiger shrimp}

\section{PENDAHULUAN}

Pembenihan udang windu pada umumnya menggunakan induk alam untuk produksi naupli. Pematangan gonad induk udang windu dilakukan hanya untuk memenuhi target produksi sehingga masa pemeliharaan induk di unit instalasi pembenihan udang windu relatif singkat. Induk-induk udang windu yang digunakan untuk proses pembenihan di Instalasi Pembenihan Udang Windu (IPUW), Balai Riset Perikanan Budidaya Air Payau dan Penyuluhan Perikanan (BRPBAP3) pada umumnya berkisar antara 20 hingga 33 hari. Masa penggunaan induk di unit pembenihan komersil yang target produksi nauplinya lebih besar biasanya lebih lama berkisar 2-4 bulan (Nawang et al., 2014). Apabila target produksi naupli sudah tercapai, maka induk yang telah digunakan akan diapkir baik jantan maupun betina. Alasan lain mengapa induk betina diapkir adalah performa reproduksi induk mengalami penurunan seiring dengan meningkatnya frekuensi pemijahannya yang diindikasikan oleh rendahnya daya tetas telur yang dihasilkan khususnya pada rematurasi (Wongprasert et al., 2006). Salah satu penyebabnya diduga adalah meningkatnya jumlah telur yang tidak fertil karena pembuahan telur yang tidak sempurna atau belum terjadi perkawinan sehingga udang betina tidak membawa spermatofor pada telikumnya (Lante \& Laining, 2016). Selain itu, kondisi induk betina yang telah kehilangan mata setelah diablasi tidak memungkinkan untuk dipelihara dalam waktu yang panjang (Primavera, 1978).

Berbeda dengan induk betina, sejauh ini informasi mengenai performa induk udang windu jantan setelah proses pematangan gonad di unit pembenihan masih sangat terbatas baik mengenai berat spermatofor maupun frekuensi rematurasinya. Namun, Lante et al. (2014) melaporkan bahwa berat spermatofor induk jantan alam yang berasal dari perairan Polman, Sulawesi Barat dan tidak diablasi sekitar 0,05 $\pm 0,01 \mathrm{~g}$ per kantong $(0,1 \mathrm{~g} / \mathrm{ekor})$. Salah satu upaya yang perlu dilakukan untuk memperpanjang masa pemeliharaan induk udang windu jantan adalah melalui manipulasi hormonal tanpa ablasi mata. Aplikasi hormon sintetis telah dilaporkan memberikan efek positif dalam memicu pematangan gonad beberapa spesis ikan (Jamroz et al., 2008; Kagawa et al., 2013; Komatsu et al., 2006; Zadmajid, 2016) maupun krustase (Laining et al., 2015; Tinikul et al., 2014; Wongprasert et al., 2006).
Jenis hormon yang diketahui mampu menstimulasi perkembangan gonad ikan di antaranya adalah kombinasi antara human chorionic gonadotropin (hCG), salmon pituitary extract (SPE) dan gonadotropin releasing hormone analogue (GnRHa) pada ikan sidat (Kagawa et al., 2013), dan oocite developer (Laining et al., 2015; Prasetyo et al., 2017; Ramdani, 2013) serta gonadotropin releasing hormone dan dopamine (Tinikul et al., 2014) pada krustase. Hormon sintetis lainnya yang sudah secara luas diaplikasikan pada ikan dan krustase adalah kombinasi salmon gonadotropin releasing hormone analogue (sGnRH-a) dengan domperidoneatau yang populer dikenal dengan nama ovaprim (Cejko et al., 2012; Genz et al., 2014; Jamroz et al., 2008; Zadmajid, 2016). Penelitian terkini pada udang windu jantan hasil budidaya menunjukkan bahwa hormon kombinasi sGnRH-a dan domperidone dapat diaplikasikan pada konsentrasi 0,1-0,2 mL/kg udang windu (Laining et al., 2016). Pada penelitian tersebut, injeksi pada konsentrasi $0,1 \mathrm{~mL} / \mathrm{kg}$ diperoleh jumlah induk yang menghasilkan spermatofor sebanyak $80,8 \%$ lebih tinggi dari induk yang diablasi sebesar $46,1 \%$ dan pada dosis $0,2 \mathrm{~mL} / \mathrm{kg}$; berat spermatofor udang lebih besar $(0,155$ g) dibandingkan dosis lainnya.

Mengingat masa penggunaan induk udang windu di unit pembenihan seharusnya perlu diperpanjang khususnya induk jantan, maka perlu dilakukan kajian mengenai performa reproduksi induk jantan yang telah diapkir dengan aplikasi manipulasi hormonal dan ablasi sebagai kontrol. Penelitian ini bertujuan untuk mengevaluasi efek injeksi hormon kombinasi salmon gonadotrophin releasing hormone analogue $(\mathrm{s} G \mathrm{nRH}-\mathrm{a})$ dan domperidone terhadap karakteristik spermatofor induk udang windu, Penaeus monodon yang telah diapkir dari unit pembenihan tanpa ablasi tangkai mata.

\section{BAHAN DAN METODE}

\section{Induk Udang Windu Apkir dan Injeksi sGnRH-a}

Hewan uji yang digunakan dalam penelitian ini adalah induk alam jantan udang windu apkiran dari hatcheri yang telah dipakai untuk produksi massal. Penelitian ini dilakukan di bak berkapasitas 4 ton sebanyak tiga bak dengan kepadatan 14 ekor/bak untuk tahap ke-1 dan 12 ekor/bak pada tahap ke-2. Udang tersebut berasal dari Aceh dengan bobot rata-rata pada udang jantan yang digunakan pada percobaan pertama 
dan kedua berturut-turut yakni 82-120 g dan 68-127 g. Selama penelitian udang windu diberi pakan segar empat kali sehari berupa cumi-cumi dan kerang Anadara granosa sebanyak 2\%2,5\%bobot kering dari biomassa induk windu. Bak pemeliharaan induk menggunakan air yang difilter dan disterilisasikan menggunakan kaporit dengan dosis 8-10 mg/L dan disuplai dengan sistem sirkulasi (flow through).

Penelitian ini terdiri atas dua tahap kegiatan di mana kegiatan pertama terdiri atas tiga perlakuan yaitu dua dosis hormon sGnRH-a dan kontrol berupa ablasi (AB). Dua dosis yang diujikan berturut-turut adalah 0,1 (OV-1) dan 0,2 (OV-2) mL/kg bobot udang. Hormon yang digunakan pada penelitian ini adalah salmon gonadotropin releasing hormon analog (sGnRH-a). Dosis yang dicobakan adalah dosis yang direkomendasikan oleh Laining et al. (2016). Aplikasi hormon dilakukan secara injeksi sekali per minggu sebanyak $3 x$ berdasarkan penelitian sebelumnya pada induk udang windu betina alam (Laining et al., 2015).

Dosis terbaik penyuntikan hormon sGnRH-a dari kegiatan pertama diaplikasikan lagi pada tahap kedua injeksi yakni 0,2 mL/kg bobot udang (OV-3). Ablasi mata (AB) merupakan kontrol seperti halnya pada injeksi tahap pertama. Metode penyuntikan pada tahap kedua ini sama dengan yang diaplikasikan pada tahap pertama.

\section{Pengamatan Perkembangan Spermatofor}

Pengamatan tingkat kematangan gonad induk jantan tidak mudah dilakukan seperti halnya pada induk betina karena proses pematangan gonadnya tidak mudah terlihat dari luar tubuhnya. Indikator yang digunakan untuk mengevaluasi tingkat kematangan gonad (spermatofor) induk jantan adalah keluarnya spermatofor dari ampula terminalis setelah diberi kejutan listrik.

Pengamatan perkembangan spermatofor pada kedua tahap penyuntikan dilakukan dengan metode yang sama. Seminggu setelah injeksi akhir dilakukan, induk jantan diberi kejutan listrik menggunakan arus DC dengan transformer sebesar $5 \mathrm{~mA}$ dan tegangan 812 volt yang dilengkapi dengan elektroda (Lante \& Laining, 2016). Ujung katoda dan anoda elektroda ditempelkan pada bagian ventral tubuh dekat gonofor di sekitar pangkal kaki jalan kelima selama \pm 2 detik untuk mengeluarkan spermatofor dari terminal ampula. Induk yang mengeluarkan spermatofor pada shok pertama dikategorikan sebagai induk yang matang gonad (maturasi) dan sebaliknya. Apabila induk jantan yang sama mengeluarkan lagi spermatofornya pada shock elektrik ke-2 dan ke-3, maka berturut-turut induk tersebut dikategorikan melakukan rematurasi ke-1 dan ke-2. Induk jantan mengeluarkan spermatofor dengan cara di-shock elektrik sebanyak tiga kali dengan interval satu minggu (Laining et al., 2016; Prasetyo et al., 2017).

Kepadatan spermatofor dihitung menggunakan Haemacytometer. Spermatofor yang dilepaskan oleh induk jantan ditimbang dan dimasukkan dalam mikrotube evendorf $1,5 \mathrm{~mL}$ dan digerus menggunakan tissue grinder kemudian ditambahkan larutan calciumfree saline solution sebanyak $1 \mathrm{~mL}$ dan selanjutnya dihitung di bawah mikroskop pada pembesaran 40 .

\section{Analisis Statistik}

Persentase induk matang gonad yang ditandai dengan keluarnya spermatofor dari terminal ampula melalui shock elektrik dianalisis secara deskriptif. Hubungan antara bobot badan dengan bobot spermatofor udang windu (data dari percobaan tahap ke-1) dan bobot spermatofor dengan jumlah spermatozoa (data dari percobaan tahap ke-2) ditentukan dengan analisis regresi di mana dua variabel dianggap memiliki hubungan yang kuat ketika nilai $r>0,5$; dan sebaliknya dua variabel dianggap lemah ketika nilai $r<0,5$. Analisis regresi dilakukan menggunakan aplikasi curve expert 1.4.

\section{HASIL DAN BAHASAN}

\section{Performa Induk Jantan Pasca Injeksi sGnRH-a Tahap 1}

Jumlah induk yang mengeluarkan spermatofor setelah diberikan kejutan listrik fase maturasi, rematurasi ke- 1 dan rematurasi ke- 2 tertera pada Tabel 1. Jumlah induk yang mengeluarkan spermatofor terbanyak pada fase maturasi, rematurasi ke-1 dan rematurasi ke-2 terjadi pada udang yang diinjeksi 0,2 $\mathrm{mL} / \mathrm{kg}$ bobot udang (OV-2) diikuti OV-1 dan AB. Hasil ini berbeda dengan yang ditemukan Laining et al. (2016) yang menyatakan penyuntikan $\mathrm{SGnRH}$-a dengan dosis $0,1 \mathrm{~mL} / \mathrm{kg}$ menghasilkan induk jantan (hasil budidaya) yang melepaskan spermatofor setelah diberikan kejutan listrik sebesar 80,8\%lebih tinggi dibandingkan dosis $0,2(46 \%)$ dan $0,3(42,3 \%$. Perbedaan tersebut diduga karena induk apkiran membutuhkan hormon gonadotropin yang lebih banyak dibandingkan induk yang tidak diapkir sehingga dosis yang dibutuhkan untuk perkembangan spermatofornya lebih tinggi.

Tabel 2 menyajikan bobot spermatofor pada maturasi, rematurasi ke-1 dan rematurasi ke-2 dan menunjukkan bahwa bobot spermatofor cenderung bertambah dengan meningkatnya dosis injeksi lebih berat yaitu 0,15 g/ekor (maturasi); 0,126 g/ekor (rematurasi ke-1) dan 0,137 g/ekor (rematurasi ke-2) 
Tabel 1. Jumlah induk jantan yang mengeluarkan spermatofor setelah diberikan kejutan listrik pada tiga waktu pematangan gonad pada tahap pertama percobaan

Table 1. Number of male broodstock releasing spermatophore through electrical shock at three maturation times on the first trial

\begin{tabular}{lcccc}
\hline \multicolumn{1}{c}{$\begin{array}{c}\text { Peubah } \\
\text { Variable }\end{array}$} & \multicolumn{3}{c}{$\begin{array}{c}\text { Dosis injeksi sGnRH-a } \\
\text { sGnRH-a doses injection }\end{array}$} \\
\cline { 2 - 5 } & AB & OV-1 & OV-2 \\
\hline $\begin{array}{l}\Sigma \text { jantan (ekor) } \\
\text { males (shrimp) }\end{array}$ & 14 & 14 & 14 \\
Rata-rata dan kisaran bobot udang jantan (g) & 100.2 & 101.7 & 102.5 \\
Mean and range of body weight of male (g) & $(85-110)$ & $(84-112)$ & $(82-120)$ \\
\hline$\Sigma$ jantan yang mengeluarkan spermatofor pada tiga siklus pematangan: & & & \\
$\Sigma$ male releasing spermatophore at three maturation cycles: & & & \\
Maturasi (Maturation) & $4(28.6 \%)$ & $5(35.7 \%)$ & $8(57.1 \%)$ \\
Rematurasi ke-1 (1st rematuration) & $2(14.3 \%)$ & $2(14.3 \%)$ & $5(35.7 \%)$ \\
Rematurasi ke-2 (2nd rematuration) & $1(7.1 \%)$ & $1(7.1 \%)$ & $3(21.4 \%)$ \\
\hline
\end{tabular}

Keterangan (Note): $* A B=$ ablasi tangkai mata; $0 V 1=$ injeksi $0,1 \mathrm{~mL} / \mathrm{kg} ; 0 \mathrm{~V} 2=$ injeksi $0,2 \mathrm{~mL} / \mathrm{kg}$

Tabel 2. Bobot spermatofor udang windu pada tiga siklus pematangan pada percobaan tahap pertama Table 2. Weight of spermatophore of tiger shrimp at three maturation cycles on the first trial

\begin{tabular}{|c|c|c|c|}
\hline \multirow{2}{*}{$\begin{array}{l}\text { Peubah } \\
\text { Variable }\end{array}$} & \multicolumn{3}{|c|}{$\begin{array}{l}\text { Dosis injeksi sGnRHa } \\
\text { sGnRH-a doses injection }\end{array}$} \\
\hline & $\mathbf{A B}$ & OV-1 & $0 \mathrm{~V}-2$ \\
\hline $\begin{array}{l}\Sigma \text { jantan (ekor) } \\
\Sigma \text { males (shrimp) }\end{array}$ & 14 & 14 & 14 \\
\hline $\begin{array}{l}\text { Rata-rata dan kisaran dari bobot udang jantan (g) } \\
\text { M ean and range of body weight of male }(\mathrm{g})\end{array}$ & $\begin{array}{c}100.2 \\
(85-110)\end{array}$ & $\begin{array}{c}101.7 \\
(84-112)\end{array}$ & $\begin{array}{c}102.5 \\
(82-120)\end{array}$ \\
\hline \multicolumn{4}{|c|}{$\begin{array}{l}\text { Bobot spermatofor pada tiga siklus pematangan (g/ekor): } \\
\text { W eight of spermatophore at three maturation cycles (g/shrimp): }\end{array}$} \\
\hline Maturasi (Maturation) & $\begin{array}{c}0.135 \pm 0.076 \\
(n=4)\end{array}$ & $\begin{array}{l}0.13 \pm 0.025 \\
(n=5)\end{array}$ & $\begin{array}{l}0.15 \pm 0.019 \\
\quad(n=8)\end{array}$ \\
\hline Rematurasi ke-1 (1st rematuration ) & $\begin{array}{l}0.11 \pm 0.014 \\
(n=2)\end{array}$ & $\begin{array}{c}0.125 \pm 0.035 \\
(n=2)\end{array}$ & $\begin{array}{c}0.126 \pm 0.036 \\
(n=5)\end{array}$ \\
\hline Rematurasi ke-2 (2nd rematuration) & $\begin{array}{l}0.13 \pm 0 \\
(n=1)\end{array}$ & $\begin{array}{l}0.1 \pm 0 \\
(n=1)\end{array}$ & $\begin{array}{c}0.137 \pm 0.006 \\
(n=3)\end{array}$ \\
\hline
\end{tabular}

Keterangan (Note): ${ }^{A} \mathrm{AB}=$ ablasi tangkai mata; $\mathrm{OV} 1=$ injeksi $0,1 \mathrm{~mL} / \mathrm{kg} ; \mathrm{OV} 2=$ injeksi $0,2 \mathrm{~mL} / \mathrm{kg}$

dengan $A B$ dan OV-1. Hal yang sama ditemukan pula pada injeksi sGnRH-a pada induk jantan udang windu hasil budidaya di mana dosis $0,2 \mathrm{~mL} / \mathrm{kg}$ menghasilkan spermatofor dengan rerata bobot 0,155 g/ekor dibandingkan dua dosis lainnya dan ablasi (Laining et al., 2016).

\section{Performa Induk Jantan Pascainjeksi sGnRH-a Tahap 2}

Jumlah induk jantan yang mengeluarkan spermatofor pada fase maturasi, rematurasi ke-1 dan rematurasi ke-2 pada injeksi tahap kedua dapat dilihat pada Tabel 3. Jumlah induk yang mengeluarkan 
Tabel 3. Jumlah induk jantan yang mengeluarkan spermatofor melalui kejutan listrik pada tiga waktu pematangan pada tahap kedua percobaan

Table 3. Number of male broodstock releasing spermatophore through electrical shock at three maturation times on the second trial

\begin{tabular}{lcc}
\hline \multicolumn{1}{c}{$\begin{array}{c}\text { Peubah } \\
\text { Variable }\end{array}$} & \multicolumn{2}{c}{$\begin{array}{c}\text { Dosis injeksi sGnRH-a } \\
\text { sGnRH-a doses injection }\end{array}$} \\
\cline { 2 - 3 } & AB & OV-3 \\
\hline$\Sigma$ jantan (ekor) & 12 & 12 \\
$\Sigma$ males (shrimp) & 98.2 & 90.7 \\
Rata-rata dan kisaran dari bobot udang jantan (g) & $(73-127)$ & $(68-115)$ \\
M ean and range of body weight of male (g) & & \\
\hline$\Sigma$ jantan yang mengeluarkan spermatofor pada tiga siklus pematangan (ekor): & & \\
$\Sigma$ male releasing spermatophore at three maturation cycles (shrimp): & $6(50 \%)$ & $7(58.3 \%$ \\
Maturasi (Maturation ) & $4(33.3 \%$ & $3(25 \%)$ \\
Rematurasi ke-1 (1st rematuration) & $6(50 \%)$ & $1(8.3 \%)$ \\
Rematurasi ke-2 (2nd rematuration) & \multicolumn{2}{c}{}
\end{tabular}

Keterangan (Note): ${ }^{*} \mathrm{AB}=$ ablasi tangkai mata; $\mathrm{OV} 3=$ injeksi $0,2 \mathrm{~mL} / \mathrm{kg}$

spermatofor terbanyak ditemukan pada fase maturasi di mana induk yang diinjeksi sGnRH-a 0,2 mL/kg bobot udang lebih tinggi yaitu 58,3\%sedangkan pada ablasi sebanyak $50 \%$ Sebaliknya pada rematurasi diperoleh jumlah induk yang mengeluarkan spermatofor lebih banyak pada $A B$ dibandingkan OV-3. Hal ini menunjukkan bahwa stimulasi pematangan spermatofor dengan injeksi sGnRH-a pada tahap kedua ini hanya berpengaruh pada fase maturasi saja. Dengan kata lain injeksi sGnRH-a hanya menstimulasi pematangan spermatofor dalam jangka waktu yang relatif singkat, berbeda dengan hasil yang diperoleh pada injeksi tahap pertama di mana efek sGnRH-a terjadi baik pada maturasi maupun untuk $2 x$ rematurasi (Tabel 1 ).

Kondisi fisiologis induk udang jantan apkiran yang digunakan pada dua tahap injeksi ini diduga berbeda sehingga menyebabkan terjadinya perbedaan respons hormonal. Prasetyo et al. (2017) juga mengamati efek singkat dari injeksi hormon oodev pada induk jantan budidaya di mana pematangan gonad pascainjeksi hanya terjadi satu kali siklus saja (maturasi) tetapi proses pematangan spermatofornya terjadi secara simultan. Sebaliknya pada rematurasi ke-1 dan rematurasi ke-2 udang yang diablasi lebih banyak menghasilkan spermatofor dibandingkan OV-3, diduga karena udang windu yang diablasi melakukan proses reproduksi secara terus-menerus akibat kehilangan sebagian kelenjar sinus dan x-organ yang terdapat pada tangkai mata yang mensekresikan hormon penghambat kematangan gonad (GIH) (Uawisetwathana et al., 2011; Prasetyo et al., 2017).
Bobot spermatofor udang windu pada maturasi, rematurasi ke-1 dan rematurasi ke-2 dapat dilihat pada Tabel 4. Data yang diperoleh menunjukkan tren yang relatif sama dengan data pematangan spermatofor di mana perlakuan $A B$ menghasilkan bobot spermatofor yang relatif lebih besar dibandingkan pada OV-3, kecuali pada rematurasi ke-2. Selain karena perlakuan, perbedaan bobot spermatofor yang diamati diduga pula diakibatkan oleh perbedaan bobot induk jantan yang diinjeksi yaitu 98,2 g pada AB dan 90,7 g pada OV-3.

Kepadatan sperma udang windu untuk perlakuan ablasi untuk fase maturasi lebih padat dibandingkan ablasi sedangkan untuk fase rematurasi ke-1 dan rematurasi ke-2 perlakuan injeksi hormon lebih padat dibandingkan ablasi. Secara umum, jumlah sel spermatozoa menunjukkan penurunan dengan meningkatnya frekuensi pemijahan untuk kedua perlakuan. Untuk lebih rinci kepadatan spermatozoa pada maturasi pertama, rematurasi ke-1 dan rematurasi ke-2 dapat dilihat pada Tabel 5.

\section{Hubungan antara Bobot Badan, Bobot Spermatofor, dan Jumlah Spermatozoa}

Hasil analisis regresi antara bobot badan induk jantan dengan bobot spermatofor untuk data yang diperoleh pada percobaan tahap ke-1 diilustrasikan pada Gambar 1. Hubungan antara bobot badan induk jantan dan bobot spermatofor bersifat linier atau bobot badan induk jantan udang windu berbanding lurus dengan bobot spermatofor dengan nilai $r=0,74$. Hasil ini menunjukkan bahwa induk jantan udang 
Tabel 4. Berat spermatofor udang windu pada tiga siklus pematangan pada percobaan tahap kedua

Table 4. Weight of spermatophore of tiger shrimp at three maturation cycles on the second trial

\begin{tabular}{|c|c|c|}
\hline \multirow{2}{*}{$\begin{array}{l}\text { Peubah } \\
\text { Variable }\end{array}$} & \multicolumn{2}{|c|}{$\begin{array}{l}\text { Dosis injeksi sGnRH-a } \\
\text { sGnRH-a doses injection }\end{array}$} \\
\hline & $\mathbf{A B}$ & OV-3 \\
\hline $\begin{array}{l}\Sigma \text { jantan (ekor) } \\
\Sigma \text { males (shrimp) }\end{array}$ & 12 & 12 \\
\hline $\begin{array}{l}\text { Rata-rata dan kisaran bo bot udang jantan (g) } \\
\text { M ean and range of body weight of male }(\mathrm{g})\end{array}$ & $\begin{array}{c}98.2 \\
(73-127)\end{array}$ & $\begin{array}{c}90.7 \\
(68-115)\end{array}$ \\
\hline \multicolumn{3}{|c|}{$\begin{array}{l}\text { Bobot spermatofor pada tiga siklus pematangan }(\mathrm{g}) \text { : } \\
\text { W eight of spermatophore at three maturation cycles }(\mathrm{g}) \text { : }\end{array}$} \\
\hline Maturasi (Maturation ) & $\begin{array}{c}0.086 \pm 0.044 \\
(n=6)\end{array}$ & $\begin{array}{c}0.067 \pm 0.014 \\
(n=7)\end{array}$ \\
\hline Rematurasi ke-1 (1st Rematuration ) & $\begin{array}{c}0.084 \pm 0.037 \\
(n=4)\end{array}$ & $\begin{array}{c}0.08 \pm 0.016 \\
(n=3)\end{array}$ \\
\hline Rematurasi ke-2 (2nd Rematuration ) & $\begin{array}{c}0.066 \pm 0.032 \\
(n=6)\end{array}$ & $\begin{array}{c}0.066 \pm 0 \\
(n=1)\end{array}$ \\
\hline
\end{tabular}

Keterangan (Note): ${ }^{*} \mathrm{AB}=$ ablasi tangkai mata; OV3= injeksi $0,2 \mathrm{~mL} / \mathrm{kg}$

Tabel 5. Jumlah spermatozoa udang windu pada tiga siklus pematangan pada percobaan tahap kedua

Table 5. Number of spermatozoa of tiger shrimp at three maturation cycles on the second trial

\begin{tabular}{|c|c|c|}
\hline \multirow{2}{*}{$\begin{array}{l}\text { Peubah } \\
\text { Variable }\end{array}$} & \multicolumn{2}{|c|}{$\begin{array}{l}\text { Dosis injeksi sGnRH-a } \\
\text { sGnRH-a doses injection }\end{array}$} \\
\hline & $\mathbf{A B}$ & OV-1 \\
\hline $\begin{array}{l}\Sigma \text { jantan (ekor) } \\
\Sigma \text { males (shrimp) }\end{array}$ & 12 & 12 \\
\hline $\begin{array}{l}\text { Rata-rata dan kisaran dari bobot udang jantan }(\mathrm{g}) \\
\text { Mean and range of body weight of male (g) }\end{array}$ & $\begin{array}{c}98.2 \\
(73-127)\end{array}$ & $\begin{array}{c}90.7 \\
(68-115)\end{array}$ \\
\hline $\begin{array}{l}\text { Jumlah spermatozoa pada tiga siklus pematangan }\left(\times 10^{6} \mathrm{sel} / \mathrm{mL}\right) \text { : } \\
\text { Number of spermatozoa at three maturation cycles; }\left(\times 10^{6} \mathrm{cell} / \mathrm{mL}\right) \text { : }\end{array}$ & & \\
\hline Maturasi (Maturation) & $101.2(n=6)$ & $89.5(n=7)$ \\
\hline Rematurasi ke-1 (1st rematuration) & $46.68(n=4)$ & $81.40(n=3)$ \\
\hline Rematurasi ke-2 (2nd rematuration) & $53.03(n=6)$ & $54.40(n=1)$ \\
\hline
\end{tabular}

windu dengan bobot badan yang lebih besar akan menghasilkan bobot spermatofor yang relatif lebih besar pula. Pola ini juga dilaporkan oleh Prasetyo et al. (2017) di mana induk udang windu jantan yang berasal dari alam bobot spermatofornya berbanding positif dengan bobot badannya.
Selanjutnya hubungan antara bobot spermatofor dan jumlah sel spermatozoa untuk data pada percobaan tahap ke-2 digambarkan pada Gambar 2. Koefisien regresi yang didapatkan hanya sebesar $r=0,14$ yang menunjukkan bahwa hubungan bobot spermatofor tidak linier dengan jumlah 


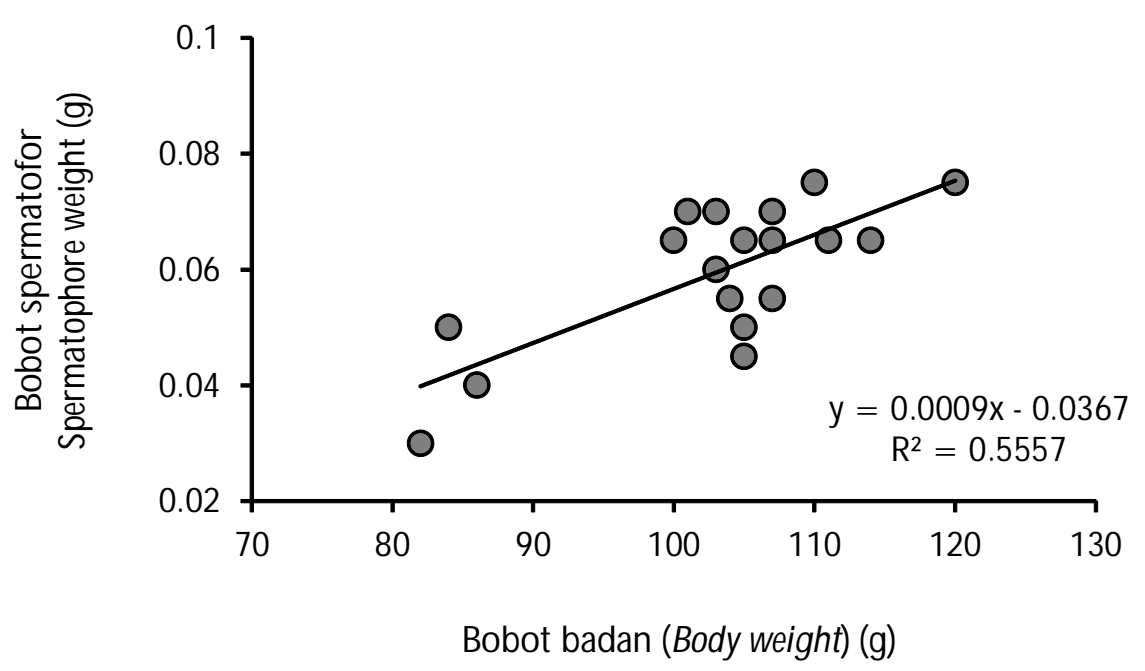

Gambar 1. Hubungan antara bo bot badan dengan bobot spermatofor induk udang windu apkir (data pada percobaan tahap 1).

Figure 1. Relationship between body weight and weight of spermatophore of discarded male tiger shrimp (pooled data from the $1^{\text {st }}$ trial).
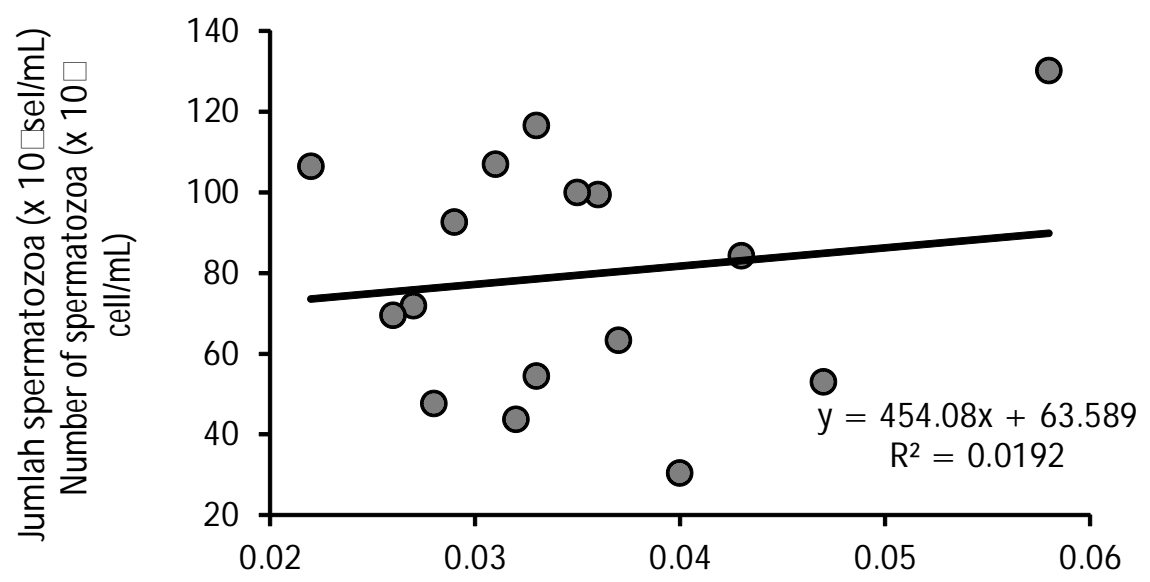

Bobot spermatofor (Spermatophore weight) (g)

Gambar 2. Hubungan antara bobot spermatofor dengan jumlah spermatozoa induk udang windu apkir (data pada percobaan tahap 2).

Figure 2. Relationship between weight of spermatophore with number of spermatozoa of discarded male tiger shrimp (pooled data from the $2^{\text {nd }}$ trial).

spermatozoanya. Hal ini juga ditemukan oleh Jiang et al. (2009) yang menyatakan hubungan antara dua variabel ini rendah atau tidak ada hubungan antara bobot spermatofor dengan jumlah sel spermatozoa (Meunpol et al., 2005; Prasetyo et al., 2017).

\section{KESIMPULAN}

Induk apkiran jantan udang windu masih dapat memproduksi spermatofor melalui stimulasi dengan cara ablasi mata dan injeksi hormon sGnRH-a pada dosis $0,2 \mathrm{~mL} / \mathrm{kg}$ bobot udang dengan tiga kali injeksi dengan interval satu minggu.

\section{UCAPAN TERIMA KASIH}

Penelitian ini didanai oleh DIPA T.A. 2015 Balai Riset Perikanan Budidaya Air Payau dan Penyuluhan Perikanan. Penulis mengucapkan terima kasih kepada teknisi Umar dan Ramadhan yang membantu selama penelitian. Penulis juga menyampaikan ucapan terima kasih kepada Dony Prasetyo (mahasiswa S2 IPB) yang ikut membantu pelaksanaan penelitian ini. 


\section{DAFTAR ACUAN}

Cejko, B.I., Targoriska, K., Kowalski, R.K., Zarski, D., Sarosiek, B., Kucharczyk, D., \& Glogowski, J. (2012). The effectiveness of hormonal preparation (Ovopel, Ovaprim, LHRHa, hCG and CPE) in stimulating spermation in dace Leuciscus leuciscus (L.). Journal of Applied Ichthyology, 28, 873-877.

Genz, J., McDougall, C.A., Kheeto, S., Arcinas, L., Burnett, D., \& Anderson, W.G. (2014). Induced spawning of wild-caught adult lake sturgeon: assessment of hormonal and stress responses, gamete quality and survival. Journal of applied Ichthyology, 30, 1565-1577.

Jamroz, M., Kurcharczyk, D., Hakuc-Blazowska, A., Krejszeff, S., Kujawa, R., Kupren, K., Kwiatkowski, M., Targonska, K., Zarski, D., Cejko, B., \& Glogowski, J. (2008). Comparing the effectiveness of ovopel, ovaprim, and LHRH analogue used in the controlled reproduction of Ide, Leuciscus idus (L.). Archives of Polish Fisheries, 16(4), 363-370.

Jiang, S.G., Huang, J.H., Zhou, F.L., Chen, X., Yang, Q.B., Wen, W.G., \& Ma, Z.M. (2009). Observations of reproductive development and maturation of male Penaeus monodon reared in tidal and earthen ponds. Aquaculture, 292, 121-128.

Kagawa, H., Fujie, N., Imaizumi, H., Masuda, Y., Oda, K., Adachi, J., Nishi, A., Hashimoto, H., Teruya, K., \& Kaji, S. (2013). Using osmotic pumps to deliver hormones to induce sexual maturation of female Japanese eels, Anguilla japonica. Aquaculture, 388-391, 30-34.

Komatsu, T., Bhandari, R.K., Kobayashi, Y., Nakamura, S., \& Nakamura, M. (2006). GnRHa-accelerated spermatogenesis in the testes of underyearling golden rabbitfish, Siganus guttatus (Bloch). Aquaculture, 257, 558-565.

Laining, A., Lante, S., \& Usman. (2015). Induksi pematangan gonad dan peningkatan tingkat pembuahan telur induk udang windu, Penaeus monodon melalui rangsangan hormonal tan pa ablasi mata. Jurnal Riset Akuakultur, 10(1), 61-68.

Laining, A., Usman, \& Rachmansyah. (2016). Induction of gonadal maturation of pond cultured male tiger shrimp, Penaeus monodon with different dosages of gonadotro pin releasing hormone analogue against eye stalk ablation. Indonesian Aquaculture Journal, 11(1), 23-30.

Lante, S., Laining, A., \& Parenrengi, A. (2014). Performa reproduksi udang windu (Penaeus monodon Fab.) jantan alam dan domestikasi tambak. Prosiding Forum Inovasi Teknologi Akuakultur 2014. Pusat Penelitian dan Pengembangan Perikanan Budidaya. Jakarta, hlm. 693-700.
Lante, S. \& Laining, A. (2016). Aplikasi inseminasi buatan pada udang windu Penaeus monodon alam menggunakan sumber dan jumlah spermatofor yang berbeda. Jurnal Riset Akuakultur, 11(3), 271280.

Meunpol, O., Meejing, P., \& Piyatiratitivorakul, S. (2005). Maturation diet based on fatty acid content for male Penaeus monodon broodstock. Aquaculture Research, 36, 1216-1225.

Nawang, A., Trismawanti, I., \& Parenrengi, A. (2014). Produktivitas telur dan daya tetas induk udang windu (Penaeus monodon) asal Aceh dan Takalar. Prosiding Forum Inovasi Teknologi Akuakultur 2014. Pusat Penelitian dan Pengembangan Perikanan Budidaya. Jakarta, hlm. 701-707.

Prasetyo, D., Laining, A., \& Sudrajat, O.A. (2017). Reproductive performances of wild male tiger shrimp, Penaeus monodon post-injection of oocyte developer without eyestalk ablation. Jurnal Akuakultur Indonesia, 16(2), 193-204.

Primavera, J.H. (1978). Induced maturation and spawning in 5 month old Penaeus monodon Fabricius by eye stalk ablation. Aquaculture, 13, 355-359.

Ramdani, H. (2013). Rekayasa hormonal pada udang vaname selama 28 hari sebagai pengganti teknik ablasi mata dalam usaha percepatan pematangan gonad. Skripsi. Departemen Budidaya Perairan. Fakultas Perikanan dan IImu Kelautan. Institut Pertanian Bogor. Bogor.

Tinikul, Y., Poljaroen, J., Tinikul, R., Anuracpreeda, P., Chotwiwatthanakun, C., Senin, S., Poomtong, T., Hanna, P.j., \& Sobhon, P. (2014). Effect of gonadotropin-releasing hormones and dopamine on ovarion maturation in the Pacific white shrimp, Litopenaeus vannamei and their presence in the ovary during ovarian development. Aquaculture, $420421,7988$.

Uawisetwathana, U., Leelatanawit, R., Klanchui, A., Prommoon, J., Klinbunga, S., \& Karoonuthaisiri, N, (2011). Insights into eyestalk ablation mechanism to induce ovarian maturation in the black tiger shrimp. PloS ONE, 6(9), e24427.

Wongprasert, K., Asuvapongpatana, S., Poltana, P., Tiensuwan, M., \& Withyachumnarnkul, B. (2006). Serotonin stimulates ovarian maturation and spawning in the black tiger shrimp, Penaeus monodon. Aquaculture, 261, 1447-1454.

Zadmajid, V. (2016). Comparative effect of human chorionic gonadotropin ( $h C G$ ) and Ovaprim ${ }^{T M}$ (sGnRHa + domperidone) on the reproductive characteristics of wild-caught male Longspine craper, Capoeta trutta (Heckel, 1843). Aquaculture, 463, 7-15. 